\title{
Urban Outdoor Thermal Comfort of The Hot-Humid Region
}

\author{
Abu Bakar, A. ${ }^{1}$, Mohamed B. Gadi ${ }^{2}$ \\ ${ }^{1}$ Assistant Professor, Kulliyyah of Architecture and Environmental Design, International Islamic University Malaysia, Jalan Gombak, \\ 53100 Kuala Lumpur, Malaysia \\ ${ }^{2}$ Associate Professor, Institute of Building Technology, Faculty of Engineering, The University of Nottingham, University Park, NG7 2RD, \\ UK
}

\begin{abstract}
The study on outdoor comfort is becoming popular due to the fact that the thermoregulatory model is seen as inadequate in explaining outdoor thermal comfort conditions. Hot-humid region can be said as experiencing a critical environmental condition because of its constantly high temperature and humidity throughout the year. Thus, this study focus on the assessment of thermal comfort of outdoor urban spaces in Kuala Lumpur, Malaysia ( $3^{\circ} 9^{\prime} \mathrm{N}$ and $101^{\circ} 44^{\prime} \mathrm{E}$ ). Survey on human response towards outdoor thermal comfort in hot-humid climate of Kuala Lumpur, Malaysia was carried out during day time between $0900 \mathrm{~h}$ to $1800 \mathrm{~h}$ along with measurement of environmental parameters such as air temperature $\left({ }^{\circ} \mathrm{C}\right)$, wind velocity $(\mathrm{m} / \mathrm{s})$, radiant temperature $\left({ }^{\circ} \mathrm{C}\right)$, relative humidity $(\%)$ and solar radiation (lux). A total of 123 samples were involved in this study which took place within four sites around Kuala Lumpur. Survey results were then correlated with the environmental parameters to further develop the comfort zone for hot-humid outdoor environment specifically for Kuala Lumpur and, generally, for hot-humid regions.
\end{abstract}

\section{Introduction}

Interest in research on outdoor thermal comfort has been increasing lately, especially in tropical regions [1],[2],[3],[4],[5],[6]. Not until recently, it has been assumed that the indoor thermal comfort theory can be applied to the outdoor. However, it has been emphasized [7] that due to the dynamic outdoor environment and such, the thermoregulatory model is seen as inadequate in explaining outdoor thermal comfort conditions. This study addresses outdoor human thermal comfort within hothumid urban open spaces by analyzing factors influencing thermal comfort, especially environmental parameters, which affect the microclimatic environment of the design itself, and the physiological aspect of the subjects - in terms of their physical activities and clothing.

\section{Urban open spaces and elements of thermal performance evaluation}

Kuala Lumpur is located at midway along the west coast of Peninsular Malaysia with geographical coordinates of $3^{\circ}$ $9^{\prime} \mathrm{N}$ and $101^{\circ} 44^{\prime} \mathrm{E}$, and thus is very much near to the equatorial line. The average temperatures is ranging between $25^{\circ} \mathrm{C}$ to $33^{\circ} \mathrm{C}$ with average relative humidity ranging from approximately $55 \%$ to $95 \%$ throughout the year. Malaysia has plenty of sunshine and solar radiation and but they are sometimes block by the cloud cover and thus, it is hard to find a day with a completely clear sky
[8]. It can be argued that Kuala Lumpur gains 12 hours (0700h to $1900 \mathrm{~h}$ ) of solar radiation every day throughout the year with the highest reading ranging from 594.4 to $625 \mathrm{Wh} / \mathrm{m}^{2}$ respectively between $1100 \mathrm{~h}$ to $1300 \mathrm{~h}$ respectively.

There were four field study sites within Kuala Lumpur - namely: the courtyards of the International Islamic University Malaysia (three courtyards: C1, C2, and C3), and the recreational area of Taman Melati (TM - a housing/residential area). Different types of sites which represented various types of built form as well as natural environment within a housing area were chosen to study the effect of these spaces on the microclimate and eventually on the human thermal comfort. These sites are also reflecting the variety of spaces that can be found in the urban area.

Street plaza, corporate foyer, urban oasis, and transit foyer are the several typology of urban spaces [9]. Courtyard is another form of open space that is widely used. It can be identified based on the degree of enclosure such as enclosed, semi-enclosed, and semi-open [10]. The orientations and shapes of courtyards affect the sunlight distribution on their facades and floors, thus affecting the microclimate of the courtyards. Thus, aspect ratio (Aspect ratio $=$ area of the courtyard floor / (average height of surrounding walls) $)^{2}$ is used to determine the degree of courtyard exposure to the sky openness that permits heating by the sun [11]. Greater aspect ratio would mean greater exposure to the sky. This affects the thermal performance of a space following the energy exchanges process such as reflected radiation, short-wave radiation, 
long-wave radiation, and evaporative exchanges [12], which eventually affect the thermal comfort of the people. There is a concern on the suitability of material used for outdoor urban spaces as there is a need to lower the ambient temperatures particularly within the hot and humid regions. The pavement used for instance can be classified as 'cool' and 'warm' materials depending on their ability in absorbing heat and reradiating it to the surrounding [13]. Greenery help to absorb great amount of radiation through the evapotranspiration process with less reflection of long wave radiations [12]. It is also said as an effective moderator of near-surface climates, particularly in the mid and low latitudes [14][15].

\section{Methodology}

This study intended to study human response in terms of thermal comfort within the outdoor urban spaces of hothumid condition. Thus, survey on thermal comfort and thermal sensation by using 123 university students as the sample was conducted together with collection of physical environmental data (refer Table 1 for the equipment used and reading taken). Thirty minutes were provided for every session of the survey for every site. Three environmental readings were taken with the interval of ten minutes for every session of each site. These readings were then averaged.

Table 1. Equipment used, measurement and unit.

\begin{tabular}{|l|l|l|l|l|l|}
\hline no & equipment & measuring & \multicolumn{3}{|c|}{ unit } \\
\hline i & Whirling psychrometer & $\begin{array}{l}\text { Dry \& wet bulb } \\
\text { temperature }\end{array}$ & $\begin{array}{l}\text { DB } \\
\left({ }^{\circ} \mathrm{C}\right)\end{array}$ & $\begin{array}{l}\text { WB } \\
\left({ }^{\circ} \mathrm{C}\right)\end{array}$ & $\begin{array}{l}\text { RH } \\
(\%) *\end{array}$ \\
\hline ii & Globe thermometer & Globe temperature & \multicolumn{3}{|c|}{${ }^{\circ} \mathrm{C}$} \\
\hline iii & Digital anemometer & Wind speed & \multicolumn{3}{|c|}{$\mathrm{m} / \mathrm{s}$} \\
\hline iv & $\begin{array}{l}\text { Cole-parmer infrared } \\
\text { thermometer }\end{array}$ & $\begin{array}{l}\text { Surface temperature } \\
\text { (ground and wall) }\end{array}$ & \multicolumn{3}{|c|}{${ }^{\circ} \mathrm{C}$} \\
\hline v & Illuminance meter & $\begin{array}{l}\text { Min/max/avg. } \\
\text { illuminance }\end{array}$ & \multicolumn{2}{|c|}{ lux } \\
\hline
\end{tabular}

* The RH is obtained by referring the depression between DBT and WBT to a chart that comes together with the whirling psychrometer.

There were three types of spatial categories identified in conducting the survey which were: semi-shaded area (under the tree), open area (under direct sunlight), and covered area (arcade or corridor) - refer Table 2. However, for TM, there were only two types of spatial categories involved which were: under the tree and under direct sunlight - refer Table 3.

Table 2. Survey time and spatial categories for the courtyards

\begin{tabular}{|l|l|c|}
\hline Semi-shaded & Open & Covered (alongside the corridors) \\
\hline $0900-0930$ & $0930-1000$ & \multirow{2}{*}{$1000-1030$} \\
\hline $1100-1130$ & $1130-1200$ & $1300-1330$ \\
\hline $1200-1230$ & $1230-1300$ & $1600-1630$ \\
\hline $1400-1430$ & $1430-1500$ & \\
\hline $1500-1530$ & $1530-1600$ & \\
\hline $1700-1730$ & $1730-1800$ & \\
\hline
\end{tabular}

Table 3. Survey time and spatial categories for TM

\begin{tabular}{|c|c|}
\hline Under a tree & Jnder direct sunlight \\
\hline $0900-0930$ & $0930-1000$ \\
\hline $1000-1030$ & \\
\hline $1100-1130$ & $1130-1200$ \\
\hline $1200-1230$ & $1230-1300$ \\
\hline
\end{tabular}

\begin{tabular}{|l|l|}
\hline $1300-1330$ & \\
\hline $1400-1430$ & $1430-1500$ \\
\hline $1500-1530$ & $1530-1600$ \\
\hline $1600-1630$ & \\
\hline $1700-1730$ & $1730-1800$ \\
\hline
\end{tabular}

In each session, the samples were divided into two groups to perform passive (1 to $3 \mathrm{met}$ ) and active ( 3 to 8 met) activities respectively for twenty minutes. The sensation scale of the PMV which is also known as the Bedford seven-point scale was used in assessing thermal sensation [16], while in assessing thermal comfort, the scale provided by ASHRAE 55 [17] (refer Table 4) was used, and these scales were adopted in the survey questionnaire for the samples to indicate their preferences. The survey questionnaire consisted of three main sections as follows:

- Section A: details on the location, date, day, weather condition and others,

- Section B: details of the sample, such as name, age, health condition and others,

- Section C: tables on comfort judgment for the sample to tick and a few open-ended questions.

Table 4. Categories of votes for thermal sensation and thermal comfort.

\begin{tabular}{|l|l|l|l|}
\hline \multicolumn{2}{|l|}{$\begin{array}{l}\text { Scale for thermal } \\
\text { sensation }\end{array}$} & \multicolumn{2}{|l|}{$\begin{array}{l}\text { Scale for thermal } \\
\text { comfort }\end{array}$} \\
\hline Scale & Description & Scale & Description \\
\hline+3 & Hot & 1 & $\begin{array}{l}\text { Very } \\
\text { comfortable }\end{array}$ \\
\hline+2 & Warm & 2 & Comfortable \\
\hline+1 & $\begin{array}{l}\text { Slightly } \\
\text { warm }\end{array}$ & 3 & $\begin{array}{l}\text { Slightly } \\
\text { comfortable }\end{array}$ \\
\hline 0 & Neutral & 4 & Neutral \\
\hline-1 & Slightly cool & 5 & $\begin{array}{l}\text { Slightly } \\
\text { uncomfortable }\end{array}$ \\
\hline-2 & Cool & 6 & Uncomfortable \\
\hline-3 & Cold & 7 & $\begin{array}{l}\text { Very } \\
\text { uncomfortable }\end{array}$ \\
\hline
\end{tabular}

During the survey, it was observed that the samples were wearing clothes with clo value from 0.5 to 0.8 which is regarded as the typical clo value among Malaysians. On top of the fieldwork, shadow analysis using Sketchup ${ }^{\mathrm{TM}}$ programme was also simulated from $0900 \mathrm{~h}$ to $1800 \mathrm{~h}$ except for C3, which ended at $1630 \mathrm{~h}$, because the whole area was already shaded from then onwards.

\section{Locations, orientations, and physical built forms of studied sites}

\subsection{The Courtyards: $\mathrm{C} 1\left(5484 \mathrm{~m}^{2}\right), \mathrm{C} 2\left(2500 \mathrm{~m}^{2}\right)$, and C3(520 $\left.\mathrm{m}^{2}\right)$}

These three types of courtyards studied represented the followings, and their images are shown in figure 1:

i. paved courtyard : named as Courtyard 1 (C1) regarded as $100 \%$ paved;

ii. partially-paved courtyard : named as Courtyard 2 (C2) - refer to Table 5; 
iii. turfed courtyard : named as Courtyard 3 (C3) regarded as $100 \%$ turfed.
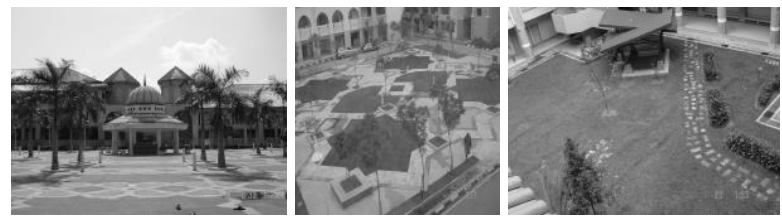

Figure 1. Courtyard 1 (left), Courtyard 2 (middle), and Courtyard 3 (right)

Table 5. Percentage of sub-areas in $\mathrm{C} 2$

\begin{tabular}{|l|c|c|}
\hline Surface material & $\mathbf{m}^{2}$ & $\mathbf{\%}$ \\
\hline Tarmac area & 1350 & 54 \\
\hline Rubber matt & 194 & 7.8 \\
\hline Grass/turfed area & 184 & 7.4 \\
\hline Paved area & 772 & 30.8 \\
\hline Total area & $\mathbf{2 5 0 0}$ & $\mathbf{1 0 0}$ \\
\hline
\end{tabular}

All these courtyards have zaguáns and arcades. Zaguán is a covered entranceway from the street to the courtyard, which acts as a wind tunnel to allow wind from outside to penetrate the courtyards [18], while an arcade (or colonnade) is a covered walkway at the sideline of a building. The height of the buildings surrounding $\mathrm{C} 1$ and $\mathrm{C} 2$ varies from 3 levels to 5 levels except for $\mathrm{C} 3$ where it is surrounded by 4 level buildings. The aspect ratio of these courtyards are identified. Following the definition of aspect ratio, $\mathrm{C} 1$ seems to demonstrate the highest degree of exposure to the sun - refer Table 6 .

Table 6. Courtyards' orientation and their aspect ratio

\begin{tabular}{|c|c|c|c|}
\hline & $\mathrm{C} 1$ & $\mathrm{C} 2$ & $\mathrm{C} 3$ \\
\hline Orientation & $22.5^{\circ}$ & $22.5^{\circ}$ & $2^{\circ}$ \\
\hline Aspect ratio & 13.81 & 4.62 & 1.86 \\
\hline
\end{tabular}

\subsection{Taman Melati - TM $\left(18211 \mathrm{~m}^{2}\right)$}

This recreational area is surrounded by 249 units of double-storey terrace houses and equipped with amenities such as a children playground, a jogging track, a badminton court, a basketball court and benches, among others. More trees are being planted in this area in a recent upgrading programme by the City Hall of Kuala Lumpur.

\subsection{Shadow analysis}

For Taman Melati, it was almost impossible to quantify the shaded area for Taman Melati and produce a percentage as the shape of the cast shadow was 'organic' as a result of the shapes of the trees. The percentage of shadowed area for the rest of the studied sites is presented in the following figure 2 .

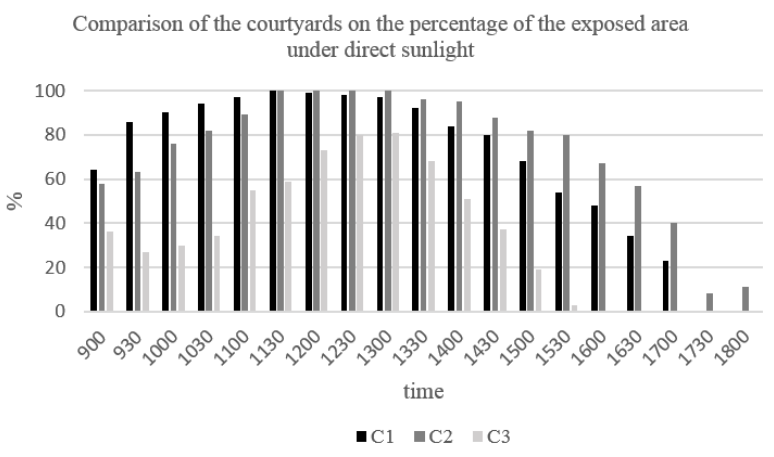

Figure 2. Comparison of the courtyards on the percentage of exposed area to the direct sunlight

C3 appears to have the shortest period of exposure under direct sunlight (from $0900 \mathrm{~h}$ to $1530 \mathrm{~h}$ ), has never reached $100 \%$ exposure to sunlight and seems to have a quite significant low percentage of area exposed to sunlight throughout the day. On average, C2 experiences the longest period of time exposed under direct sunlight compared to $\mathrm{C} 1$ and $\mathrm{C} 3$. Between $\mathrm{C} 1$ and $\mathrm{C} 2, \mathrm{C} 1$ seems to have a higher percentage of exposed area from $0900 \mathrm{~h}$ until they were equally the same at $1130 \mathrm{~h}$ before $\mathrm{C} 2$ starts to produce a higher percentage than $\mathrm{C} 1$ towards $1800 \mathrm{~h}$. In short, C2 can be determined as the courtyard that is highly exposed to the sun with a higher percentage of sunlit area throughout the day, while C3 is the total opposite in terms of results. Based on shadow simulation, it is concluded that the physical built forms of these sites greatly influence the amount of areas exposed to direct sunlight. Greater aspect ratio reading indicates that wider areas of those sites are being exposed to sunlight.

\subsection{The microclimate}

The environmental parameters considered in studying the microclimate of those sites are dry bulb temperature (DBT), wet bulb temperature (WBT), surface temperature of floor (ST-F), and surface temperature of wall (ST-W):

\section{i. $D B T, W B T, G T, S T-F \& S T-W\left({ }^{\circ} C\right)$}

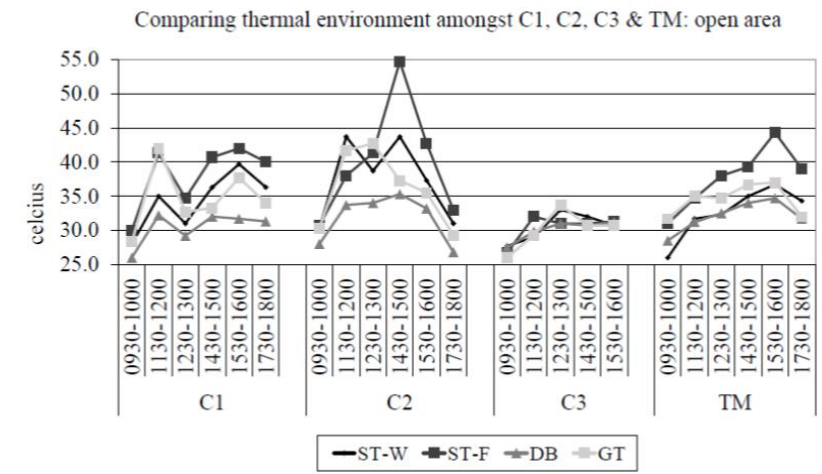

(a) open area 


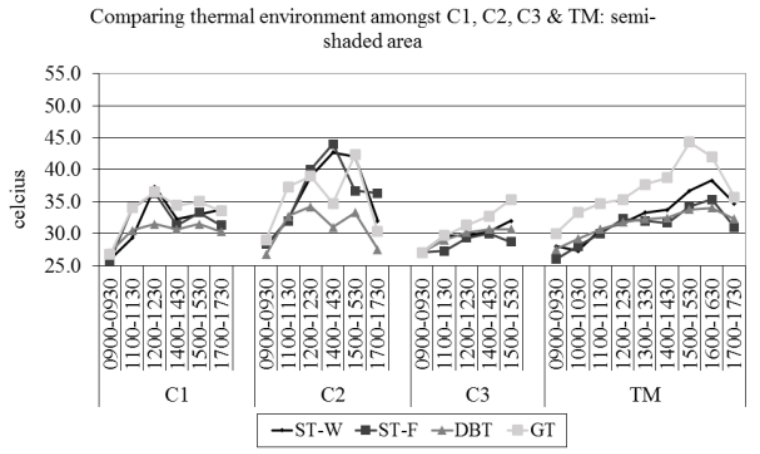

(b) semi-shaded area

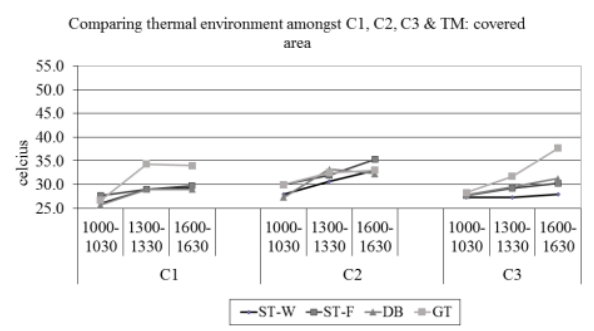

(c) covered area

Figure 3. Comparison of sites' thermal environment by spatial categories: open, semi-shaded, and covered areas

From the above graphs, it can be clearly seen that the thermal environment for the open area is hotter than the semi-shaded area, followed by the covered area. The gap among the variables plotted is wider for the open area than the semi-shaded area. C3 seems to have a narrower gap among the variables throughout the studied spatial categories while C2 is the total opposite. However, the gap amongst these variables seems narrow for the covered area. This suggests that solar radiation plays an important role in influencing the thermal environment of an area/space.

\section{ii. Illuminance (lux)}

Table 7. Minimum and maximum readings of illuminance by sites and spatial categories

\begin{tabular}{|c|c|c|c|c|c|c|}
\hline & ss & open & covered & ss & open & covered \\
\hline & \multicolumn{5}{|c|}{ C1 } & \multicolumn{3}{|c|}{ C2 } \\
\hline min ILL x 1000 (lux) & 2 & 1.2 & 0.16 & 0.3 & 2 & 0.12 \\
\hline $\max$ ILL x 1000 (lux) & 114.4 & 94.5 & 0.5 & 64.5 & 91.6 & 0.9 \\
\hline & \multicolumn{5}{|c|}{ C3 } & \multicolumn{3}{|c|}{ TM } \\
\hline $\min$ ILL x 1000 (lux) & 2.5 & 3.1 & 0.19 & 16.4 & 3.3 & - \\
\hline $\max$ ILL x 1000 (lux) & 166 & 111.6 & 0.9 & 106 & 41.7 & - \\
\hline
\end{tabular}

Based on Table 7, the minimum and maximum illuminances recorded throughout the sites are 120 lux and 166000 lux respectively. The value is greatly influenced by the spatial categories and sky condition.

\section{iii. Relative humidity (\%)}

Table 8. Minimum and maximum readings of the $\mathrm{RH}$ by sites and spatial categories

\begin{tabular}{|c|c|c|c|c|c|c|}
\hline & ss & open & covered & ss & open & covered \\
\hline & \multicolumn{5}{|c|}{ C1 } & \multicolumn{4}{c|}{ C2 } \\
\hline Min RH (\%) & 50.7 & 55.7 & 67.7 & 49.3 & 50.7 & 53 \\
\hline Max RH (\%) & 79.3 & 89.7 & 87.3 & 80.3 & 78 & 74.7 \\
\hline & \multicolumn{5}{|c|}{ C3 } & \multicolumn{4}{c|}{ TM } \\
\hline Min RH (\%) & 63.3 & 70 & 61 & 51.7 & 49.7 & - \\
\hline Max RH (\%) & 81 & 82 & 78.7 & 85 & 82.3 & - \\
\hline
\end{tabular}

Based on Table 8 , the minimum and maximum readings of the $\mathrm{RH}$ recorded throughout the site are $49.3 \%$ and $89.7 \%$ respectively.

iv. Wind speed $(\mathrm{m} / \mathrm{s})$

Table 9. Minimum and maximum readings of wind speed by sites and spatial categories

\begin{tabular}{|c|c|c|c|c|c|c|}
\hline & ss & open & covered & ss & open & covered \\
\hline & \multicolumn{3}{|c|}{$\mathrm{C} 1$} & \multicolumn{4}{c|}{ C2 } \\
\hline $\min$ WS (m/s) & 0.1 & 0.1 & 0.03 & 0 & 0 & 0.03 \\
\hline $\max$ WS (m/s) & 4.2 & 3.5 & 0.6 & 3.1 & 1.8 & 1 \\
\hline & \multicolumn{3}{|c|}{$\mathrm{C} 3$} & \multicolumn{5}{c|}{ TM } \\
\hline $\min$ WS (m/s) & 0 & 0 & 0 & 0.3 & 0 & - \\
\hline $\max$ WS (m/s) & 0.3 & 0.17 & 0.5 & 2.4 & 3.2 & - \\
\hline
\end{tabular}

Based on Table 9, it can be seen that the minimum wind speed captured throughout these sites was $0 \mathrm{~m} / \mathrm{s}$ while the maximum speed was $4.2 \mathrm{~m} / \mathrm{s}$. It can be said that the ground wind speed in Kuala Lumpur, Malaysia, is mild most of the time where strong wind, or gale, is seldom experienced.

\section{v. Surface temperature $\left({ }^{\circ} \mathrm{C}\right)$}

Although the height of buildings surrounding the courtyards varies from 3 to 5 levels, the surface temperature readings were taken up to the third level only.

Table 10. Highest surface temperature according to level of each courtyard

\begin{tabular}{|l|l|l|l|}
\hline Level & $\mathrm{C} 1$ & $\mathrm{C} 2$ & $\mathrm{C} 3$ \\
\hline 1 & $41^{\circ} \mathrm{C}$ & $45^{\circ} \mathrm{C}$ & $29^{\circ} \mathrm{C}$ \\
\hline 2 & $41^{\circ} \mathrm{C}$ & $42^{\circ} \mathrm{C}$ & $29^{\circ} \mathrm{C}$ \\
\hline 3 & $41^{\circ} \mathrm{C}$ & $42^{\circ} \mathrm{C}$ & $32^{\circ} \mathrm{C}$ \\
\hline
\end{tabular}

In looking at Table 10 above, it seems that $\mathrm{C} 2$ gives the highest reading for the façades' surface temperature. This could possibly be due to the radiant heat produced by the black tarmac that surrounds the perimeter of $\mathrm{C} 2$.

Based on the analysis, it is suggested that each and every site produced different microclimate. These may have been due to the differences in their built forms, geographical locations, orientations, elements contained within their spaces and weather types during the survey and fieldwork conducted.

\section{Comfort votes}

The ASHRAE 55 [17] outlines that a thermally acceptable environment is where at least $80 \%$ of the occupants do not express any dissatisfaction. This refers to indoor 
environment, where the environmental condition is controlled and stable. However, it is suggested that this percentage should be lowered to $70 \%$ when dealing with dynamic outdoor environment, with great environmental fluctuations throughout the day and, also, taking into account that people nowadays do not normally spend most of their time outdoor [18]. The percentage of $70 \%$ represents more than two-third of the number of occupants, which is thought as more reasonable as it still represents the majority.

The following analysis also shows that thermal comfort vote on comfortable and neutral are combined as comfortable-neutral or comft-neu. The reason is due to the fact that when assessing a rather complex thermal comfort preferences of people and, especially when it involves dynamic outdoor environment, neutral comfort category can and is suggested to be taken as non-existence discomfort to the people. This is in line with the way thermal comfort is defined by the ASHRAE 55 as mentioned earlier.

In analysing the survey data for the courtyards and TM, certain procedures were strategized. Firstly, the measure of association between thermal sensation and thermal comfort was conducted to determine the degree of corelationship between these two variables. Due to the irregular number of samples for each site, the samples were filtered to standardise their quantities. In doing so, three ways of filtering the samples were carried out to reduce bias in omitting the samples. A comparison between unfiltered and filtered data was also conducted.

Referring to result obtained, the ranking of studied sites in terms of samples' thermal preferences was identified. This process then led to identifying the most comfortable site and the most uncomfortable site. Based on these two identified sites' categories, further analysis was carried out to compare their environmental conditions and relate them to the samples' votes. The range of environmental parameters involved, where at least $70 \%$ of the samples voted for comfortable-neutral, was identified.

Based on the survey data, it is proved that there is a strong relationship and significant correlation between thermal comfort and thermal sensation in which for the context of this study - the hotter the environment, the more uncomfortable it becomes for samples. Thus, the following conclusions are generated:

- The result obtained shows an opposite preferences or votes by subjects in tropical Kuala Lumpur compared to those in temperate countries as people in temperate countries normally perceive a hotter environment as the more comfortable one.

- Temperature: The temperature set as 'comfortable' by subjects in Kuala Lumpur is significantly higher than those in temperate countries. According to the PMV, the temperature in Kuala Lumpur is theoretically too high and, yet, the subject is found to be comfortable with it. This might be due to the reason that those samples were already acclimatized and adapted to this type of climate condition.

When analysed based on thermal comfort votes throughout the investigated sites, it is concluded that votes on 'comft-neu' is relatively high compared to votes on 'uncomfortable', except for TM, where the difference is quite small. Thus, it is suggested that, even though the outdoor weather condition is extreme compared to indoor environment, people seem to be able to tolerate and compromise on the condition. Based on the spatial category with combined studied sites, the percentage of samples (doing either passive or active activities) voting for 'comfortable', 'neutral' and 'uncomfortable' are tabulated in Table 11 as follows:

Table 11. Percentage of samples voting according to comfort votes by spatial categories

\begin{tabular}{|c|c|c|c|c|c|c|c|c|c|}
\hline & \multicolumn{3}{|c|}{ semi-shaded } & \multicolumn{3}{|c|}{ open } & \multicolumn{3}{|c|}{ shaded } \\
\hline & 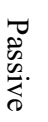 & 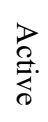 & $\begin{array}{l}\tilde{D} \\
\Xi \\
\overrightarrow{0} \\
\equiv\end{array}$ & 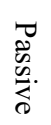 & 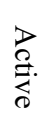 & 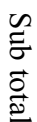 & 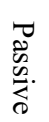 & 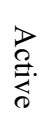 & 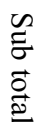 \\
\hline \multirow{2}{*}{$\begin{array}{l}\text { Comforta } \\
\text { ble }\end{array}$} & 15 & 12 & 28 & 11 & 13 & 2 & 15 & 14 & 30 \\
\hline & .5 & 9 & .4 & 7 & .3 & 5 & .9 & 6 & .5 \\
\hline \multirow[t]{2}{*}{ Neutral } & 14 & 14 & 28 & 13 & 13 & 2 & 16 & 16 & 33 \\
\hline & .1 & & .1 & .3 & .7 & 7 & .9 & .9 & .8 \\
\hline \multirow{2}{*}{$\begin{array}{l}\text { Uncomfo } \\
\text { rtable }\end{array}$} & 20 & 22 & 43 & 27 & 20 & 4 & 19 & 15 & 35 \\
\hline & .8 & .7 & .5 & .6 & .4 & 8 & .8 & .9 & .7 \\
\hline Total & \multicolumn{3}{|c|}{$100 \%$} & \multicolumn{3}{|c|}{$100 \%$} & \multicolumn{3}{|c|}{$100 \%$} \\
\hline
\end{tabular}

From Table 11, it can be seen that for the vote on 'neutral', the difference in the percentage between active and passive samples is quite small, which is between $0.1 \%$ to $0.4 \%$. Therefore, focus is given to votes on 'comfortable' and 'uncomfortable'. Votes on 'uncomfortable' is higher than on 'comfortable' and 'neutral' throughout the study for both active and passive samples. Therefore, it is suggested that since more samples felt uncomfortable throughout the survey period, this also means that outdoor environment in hot-humid climate were not preferable most of the time.

Based on the procedures applied, the following table shows the environmental conditions and parameters range as voted 'comfortable' by not less than $70 \%$ samples.

Table 12. Environmental range for "comfortable" votes $(\geq 70 \%)$.

\begin{tabular}{|c|c|c|c|c|c|c|c|c|c|c|c|}
\hline \multirow{2}{*}{\multicolumn{2}{|c|}{$\begin{array}{l}\text { comfort } \\
\text { able }\end{array}$}} & \multirow[b]{2}{*}{$\begin{array}{l}\text { tim } \\
\mathrm{e}\end{array}$} & \multirow[b]{2}{*}{$\begin{array}{l}\mathrm{D} \\
\mathrm{BT} \\
\end{array}$} & \multirow[b]{2}{*}{$\begin{array}{l}\mathrm{W} \\
\mathrm{BT} \\
\end{array}$} & \multirow[b]{2}{*}{$\begin{array}{l}\mathrm{R} \\
\mathrm{H} \\
\end{array}$} & \multirow[b]{2}{*}{$\begin{array}{l}\mathrm{G} \\
\mathrm{T}\end{array}$} & \multicolumn{2}{|c|}{ WS } & \multicolumn{2}{|l|}{ ST } & \multirow[b]{2}{*}{$\begin{array}{l}\text { avg } \\
\text { ill } \\
\end{array}$} \\
\hline & & & & & & & $\begin{array}{l}\mathrm{mi} \\
\mathrm{n}\end{array}$ & $\begin{array}{l}\mathrm{m} \\
\mathrm{ax}\end{array}$ & $\begin{array}{l}\text { flo } \\
\text { or }\end{array}$ & $\begin{array}{l}\text { wa } \\
\text { ll }\end{array}$ & \\
\hline & \multirow{2}{*}{$\begin{array}{l}\mathrm{C} \\
2\end{array}$} & $\begin{array}{l}110 \\
0- \\
113 \\
0\end{array}$ & $\begin{array}{l}32 . \\
7\end{array}$ & $\begin{array}{l}25 . \\
5\end{array}$ & $\begin{array}{l}54 \\
.7\end{array}$ & $\begin{array}{l}37 \\
.3\end{array}$ & $\begin{array}{l}0 . \\
1\end{array}$ & $\begin{array}{l}1 . \\
2\end{array}$ & 32 & $\begin{array}{l}32 \\
.3\end{array}$ & $\begin{array}{l}417 . \\
3\end{array}$ \\
\hline & & $\begin{array}{l}140 \\
0- \\
143 \\
0 \\
\end{array}$ & 31 & $\begin{array}{l}25 . \\
8\end{array}$ & $\begin{array}{l}66 \\
.3 \\
\end{array}$ & $\begin{array}{l}34 \\
.7 \\
\end{array}$ & 0 & $\begin{array}{l}0 . \\
5 \\
\end{array}$ & 44 & $\begin{array}{l}42 \\
.7 \\
\end{array}$ & $\begin{array}{l}895 . \\
3 \\
\end{array}$ \\
\hline & $\begin{array}{l}\mathrm{C} \\
3\end{array}$ & $\begin{array}{l}140 \\
0- \\
143 \\
0\end{array}$ & $\begin{array}{l}30 . \\
7\end{array}$ & 25 & $\begin{array}{l}63 \\
.3\end{array}$ & $\begin{array}{l}32 \\
.7\end{array}$ & 0 & $\begin{array}{l}0 . \\
4\end{array}$ & 30 & $\begin{array}{l}30 \\
.3\end{array}$ & $\begin{array}{l}549 \\
8.3\end{array}$ \\
\hline & $\begin{array}{l}\mathrm{T} \\
\mathrm{M}\end{array}$ & $\begin{array}{l}090 \\
0- \\
093 \\
0 \\
\end{array}$ & $\begin{array}{l}27 . \\
5\end{array}$ & $\begin{array}{l}25 . \\
5\end{array}$ & 85 & 30 & 0 & $\begin{array}{l}0 . \\
1\end{array}$ & 26 & 28 & $\begin{array}{l}109 \\
45\end{array}$ \\
\hline $\begin{array}{l}\text { ope } \\
\mathrm{n}\end{array}$ & $\begin{array}{l}\mathrm{C} \\
2 \\
\end{array}$ & $\begin{array}{l}113 \\
0-\end{array}$ & $\begin{array}{l}33 . \\
7\end{array}$ & $\begin{array}{l}25 . \\
3 \\
\end{array}$ & $\begin{array}{l}50 \\
.7\end{array}$ & $\begin{array}{l}41 \\
.7\end{array}$ & 0 & $\begin{array}{l}2 . \\
8\end{array}$ & 38 & $\begin{array}{l}43 \\
.7\end{array}$ & $\begin{array}{l}557 . \\
8\end{array}$ \\
\hline
\end{tabular}




\begin{tabular}{|l|l|l|l|l|l|l|l|l|l|l|l|}
\hline & & $\begin{array}{l}120 \\
0\end{array}$ & & & & & & & & & \\
\hline
\end{tabular}

The dry bulb temperatures are averaged and giving $31.12{ }^{\circ} \mathrm{C}$ as the average DBT. The following thermal neutrality models are administered by applying the averaged dry bulb temperature. The results are compared as follows:

i. Thermal neutrality model 1 [19]:

$$
\begin{aligned}
\mathrm{T}_{\mathrm{n}}= & 17.6+0.31 \mathrm{~T}_{\text {ave }} \\
& =17.6+0.31(31.12) \\
& =\mathbf{2 7 . 2 5}^{\mathbf{0}} \mathbf{C}
\end{aligned}
$$

(where $\mathrm{T}_{\text {ave }}$ is the outdoor average dry bulb temperature)

ii.Thermal neutrality model 2 [20]:

$$
\begin{aligned}
\mathrm{T}_{\mathrm{n}} & =2.56+0.831 \mathrm{~T}_{\mathrm{m}} \\
& =2.56+0.831(31.12) \\
& =\mathbf{2 8 . 4 2}^{\circ} \mathbf{C} .
\end{aligned}
$$

(where $\mathrm{T}_{\mathrm{m}}$ is the mean temperature for the study on indoor comfort in tropical region, case study of Dhaka)

These results show differences in reading by $1.17^{\circ} \mathrm{C}$. When compared with the averaged dry bulb temperature itself $\left(31.12^{\circ} \mathrm{C}\right)$, the difference for the former is $3.87{ }^{\circ} \mathrm{C}$ while the latter is $2.7{ }^{\circ} \mathrm{C}$. Hence, it is suggested that the thermal neutrality model 2 is more appropriate for Kuala Lumpur as the value of $28.42^{\circ} \mathrm{C}$ falls within the range of dry bulb temperature found in Table 8.33 , while thermal neutrality model 1 is situated outside the ranges of $27.5-$ $33.7^{\circ} \mathrm{C}$.

Referring to Table 12, it is reasonable to take a minimum of $27.5^{\circ} \mathrm{C}$ and a maximum of $33.7^{\circ} \mathrm{C}$ from the readings of dry bulb temperature and a minimum reading of $\mathbf{5 0 . 7 \%}$ and a maximum reading of $\mathbf{8 5 \%}$ for relative humidity to propose the comfort zone for hot-humid urban outdoor spaces of Kuala Lumpur, Malaysia. However, it should be remembered that the presence of wind speed of at least $\mathbf{0 . 1} \mathbf{m} / \mathbf{s}$ is a requirement in light of this scenario.

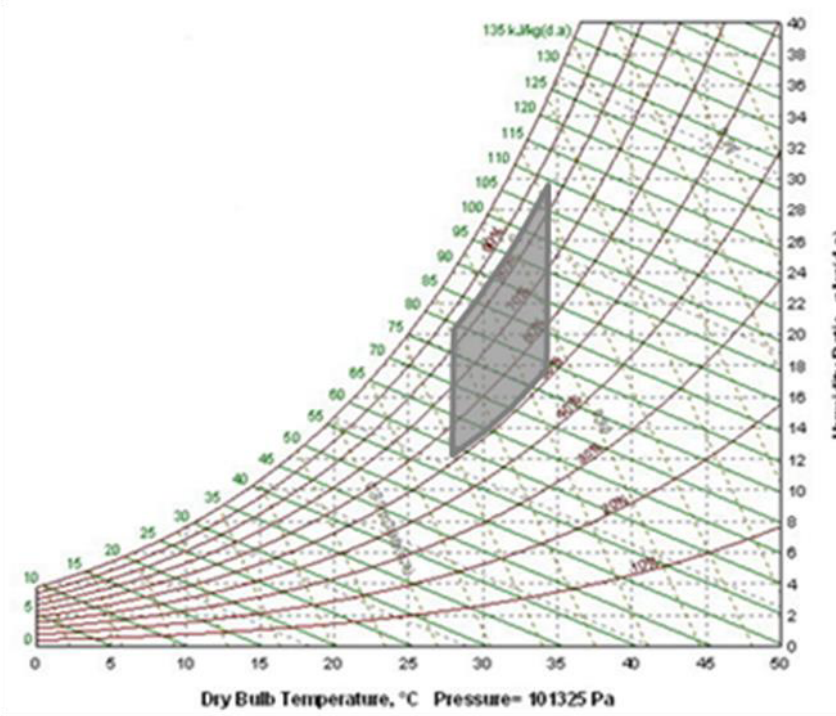

Figure 4. Proposed comfort zone for outdoor spaces of Kuala Lumpur

\section{Conclusion}

The proposed comfort zone of the outdoor environment of Kuala Lumpur can be used to monitor the environmental condition (climatically). If the climate range falls within the zone, then it is suggested that the outdoor environment is thermally comfortable most of the time for users.

Thermal comfort can be perceived as one of the tools used to study the quality of the evironment in which humans live. It may function as an indicator to study changes in the physical environment in relation to human comfort level. Hence, it is suggested that urban monitoring in terms of its climate and landscape changes for Kuala Lumpur must be conducted and recorded closely because, as the biggest city in a developing country like Malaysia, Kuala Lumpur could not stop from experiencing rapid urban form changes or perhaps to slow down its processes due to inter-related needs of the economy and built environment in particular. However, in an attempt to improve the quality of life through economic development, the lives of the current and the future generations should not be jeopardized.

\section{Acknowledgement}

The Ministry of Science, Technology and Innovation, Malaysia provided the scholarship while the International Islamic University granted the full-pay leave during this study.

\section{References}

1. Salleh, E., (1994), Tropical urban outdoor environment and human thermal comfort, The Architectural Association Graduate School, Ph.D. thesis

2. Ahmed, K.S., (1996), Approaches to bioclimatic urban design for the tropics with special reference to Dhaka, Bangladesh, The Architectural Association Graduate School, Ph.D. thesis.

3. Spagnolo, J., and de Dear, R., (2003), A field study of thermal comfort in outdoor and semi-outdoor environments in subtropical Sydney, Australia, Building and Environment, Vol. 38, pp. 721-738.

4. Chun, C., Kwok, A., and Tamura, A., (2004), Thermal comfort in transitional spaces - basic concepts: literature review and trial measurement, Building and Environment, Vol. 39, pp. 1187-1192.

5. Johansson, E., (2006), Influence of urban geometry on outdoor thermal comfort in a hot dry climate: A study in Fez, Morocco, Building and Environment, Vol. 41, pp. 1326-1338.

6. Johansson, E., and Emmanuel, R., (2006), The influence of urban design on outdoor thermal comfort in the hot, humid city of Colombo, Sri Lanka, Int. Journal of Biometeorology, Vol. 51, pp. 119-133.

7. Nikolopoulou, M., and Lykoudis, S., (2006), Thermal comfort in outdoor urban spaces: analysis across different European countries, Building and Environment, Vol. 41, pp. 1455-1470. 
8. Website of the Meteorological Dept. of Malaysia, [online]. Available at: <http://www.kjc.gov.my> [March 2007].

9. Marcus, C.C., Francis, C., and Russell, R., (1998), Urban plazas, In: Marcus, C.C., and Francis, C. eds., People places: design guidelines for urban open space (2nd edition), New York, Van Nostrand Reinhold, pp. 13-84.

10. Hyde, R., (2000), Climate responsive design: a study of buildings in moderate and hot humid climates, London, Spon Press.

11. Reynolds, J.S., (2002), Courtyards: aesthetic, social, and thermal delight, Canada, John Wiley \& Sons, Inc

12. Muhaisen, A.S., (2005), Prediction of the solar performance of courtyard buildings with different forms and various climatic regions, using a new computer model. Ph.D. thesis, University of Nottingham.

13. Doulos, L., Santamouris, M., and Livada, I., (2004), Passive cooling of outdoor urban spaces. The role of materials, Solar Energy, Vol. 77, pp. 231-249.

14. Taha, H., (1997), Urban climates and heat islands: albedo, evapotranspration, and anthropogenic heat, Energy and Buildings, Vol. 25, pp. 99-103.

15. Rosenfeld, A.H., Akbari, H., Romm, J.J., and Pomerantz, M., (1998), Cool communities: strategies for heat island mitigation and smog reduction, Energy and Buildings, Vol. 28, pp. 51-62.

16. ISO 7730: 1994(E), Moderate thermal environments Determination of the PMV and PPD indices and specification of the conditions for thermal comfort.

17. ASHRAE 55, (1992), Thermal Environmental Conditions for Human Occupancy, American Society of Heating, Refrigerating and Air-Conditioning Engineers.

18. Fanger, P.O., (1970), Thermal comfort: analysis and applications in environmental engineering, Copenhagen, Danish Technical Press.

19. Square One, Human Comfort-comfort prediction, [online]. Available at:

$<$ http://www.squ1.com/site.html $>$ [8 June 2005].

20. Ahmed, Z.N., (1995), Temperature standards for the tropics?, In: Nicol, J. F., Humphreys, M., Sykes, O. and Roaf, S., eds., (1995). Standards for thermal comfort: indoor air temperature standards for the 21st century ( $1^{\text {st }}$ edition), London, Chapman \& Hall, pp. 3139. 